\title{
Electroanalytical Determination of 4-Nitrophenol by Square Wave Voltammetry on Diamond Electrodes
}

\author{
Valber de A. Pedrosa, Lúcia Codognoto and Luis Alberto Avaca* \\ Instituto de Química de São Carlos, Universidade de São Paulo, CP 780, 13560-970 São Carlos - SP, Brazil
}

\begin{abstract}
O comportamento voltamétrico do 4-nitrofenol foi estudado em meio aquoso sobre o eletrodo de diamante dopado com boro usando a voltametria de onda quadrada. Após a otimização dos parâmetros experimentais, o estudo foi realizado em tampão Britton-Robinson com pH 6,0. Nestas condições foi observado somente um pico de oxidação em torno de $1,0 \mathrm{~V}$ vs. $\mathrm{Ag} / \mathrm{AgCl}$ com transferência de dois elétrons e um processo controlado pela adsorção das espécies na superfície do eletrodo. O limite de detecção (LD) obtido foi de $2,8 \mu \mathrm{g} \mathrm{L}^{-1}$. Este resultado foi comparado com o obtido nas mesmas condições experimentais mas utilizando o pico de redução do 4-nitrofenol em torno de $-0,8 \mathrm{~V} v s \mathrm{Ag}$ / $\mathrm{AgCl}\left(\mathrm{LD}=4,2 \mu \mathrm{g} \mathrm{L}^{-1}\right)$. Os dois valores obtidos para o $\mathrm{LD}$ se encontram dentro do limite exigido pela legislação para água potável $\left(30 \mu \mathrm{g} \mathrm{L}^{-1}\right)$. A combinação da voltametria de onda quadrada com o eletrodo de diamante dopado com boro mostrou ser uma excelente e desejável alternativa para a determinação analítica de compostos orgânicos.
\end{abstract}

The anodic voltammetric behavior of 4-Nitrophenol on a Boron-doped diamond electrode in aqueous solution has been studied using square wave voltammetry. After optimization of the experimental conditions, that model molecule was analyzed in pure water solutions using a BrittonRobinson buffer with $\mathrm{pH} 6.0$ as the supporting electrolyte. Oxidation occurs at $1.0 \mathrm{~V} v \mathrm{~s}$. $\mathrm{Ag} / \mathrm{AgCl}$ in an irreversible two-electron process controlled by adsorption of the species. The detection limit (DL) obtained was $2.8 \mu \mathrm{g} \mathrm{L}^{-1}$ This result was comparable to that obtained from reduction of the molecule at $-0.8 \mathrm{~V} v$ s. $\mathrm{Ag} / \mathrm{AgCl}$ under the same experimental conditions $\left(\mathrm{DL}=4.2 \mu \mathrm{g} \mathrm{L}^{-1}\right)$. Both DL values are within the limits required by the legislation for drinking water $\left(30 \mu \mathrm{g} \mathrm{L}^{-1}\right)$. The combination of square wave voltammetry and diamond electrodes has proved to be an interesting and desirable alternative for the analytical determination of organic molecules.

Keywords: 4-nitrophenol, square wave voltammetry, diamond electrodes

\section{Introduction}

The analysis of phenols and substituted phenols in natural waters and effluents is of prime importance for environmental control due to their appearance from a wide range of activities. These compounds have toxic effect on humans, animals and plants and they give an undesirable taste and odor to drinking water, even at very low concentration. For these reasons, many phenolic compounds have been included in the environmental legislation. In particular, 4-nitrophenol (4-NP) is one of the nitrophenols cited in the List of Priority Pollutants of the U.S.A. Environmental Protection Agency (EPA). ${ }^{1,2} 4-$ $\mathrm{NP}$ is a hazardous substance that can cause a high environmental impact due to its toxicity and persistence.

* e-mail: avaca@iqsc.sc.usp.br
The origin of such contamination comes from manufacturing, chemical industry and agricultural practices. ${ }^{3}$ Moreover, widely used organophosphorus pesticides yield nitrophenols as the initial and major degradation product. ${ }^{4}$

The detection of nitrophenols is usually carried out by chromatographic techniques sometimes associated to mass spectrometry for identification. ${ }^{5,6}$ Although routinely used, these techniques are relatively expensive and not free from drawbacks since they can often include lengthy sample preparation and analysis time.

Electrochemical methods for detection and quantification of pollutants have attracted very little attention so far. This is surprising due to the low cost and short analysis time that can be achieved using these methods. ${ }^{7}$ Meanwhile, some reports in the literature have described the determination of nitrophenols by polarography, cyclic voltammetry and differential pulse voltammetry on $\mathrm{Hg}$ electrodes. ${ }^{8,9}$ 
Among the electroanalytical techniques presently used, square wave voltammetry (SWV) has proved to be extremely sensitive for the detection of organic molecules. ${ }^{10,11}$ It also allows extracting valuable information on the characteristics of the involved charge transfer process that can be profitably employed for a subsequent destruction of undesirable compounds by electrochemical treatments. However, the utilization of SWV on borondoped diamond (BDD) electrodes is not straightforward and a careful choice and optimization of the experimental parameters is required.

Boron-doped diamond electrodes have received much attention in recent times due to its very large electrochemical window resulting from the low reactivity of its surface. ${ }^{12-15}$ As a consequence, BDD electrodes can be used at very high potential values, either negative or positive, without promoting the electrolyte decomposition thus offering an excellent alternative to mercury for electroanalytical purposes. Moreover, the capacitive currents on BDD surfaces are extremely low resulting in an enhanced sensibility of the measurements. Additionally, this material readily produces $\mathrm{OH}$ radicals on its surface at high positive potentials, thus allowing the electrochemical combustion of organic molecules present in solution. ${ }^{16-18}$

Recent works reported in the literature ${ }^{19-21}$ have shown that several organic and bio-molecules can be satisfactorily determined using BDD electrodes. Codognoto et al..$^{22}$ have reported the development of an appropriate methodology for the analytical determination of pentachlorophenol in pure and contaminated waters by means of square wave voltammetric oxidation on a boron-doped diamond electrode. A detection limit of $5.5 \mu \mathrm{g} \mathrm{L}^{-1}$ was calculated for pure water while in heavily contaminated samples it was $15.5 \mu \mathrm{g} \mathrm{L}^{-1}$ indicating that the BDD electrode is little sensitive to impurities in the sample.

This work describes the development and optimization of a SWV method for the determination of 4-NP in pure water using a boron-doped diamond electrode as well as a comparison of the results obtained by either oxidation or reduction of this model molecule on that type of electrode surface.

\section{Experimental}

A conventional three-electrode cell with a $\mathrm{Ag} / \mathrm{AgCl}$ (3.0 $\left.\mathrm{mol} \mathrm{L}^{-1}\right)$ reference system and a Pt wire as auxiliary electrodes, respectively, was used. The BDD working electrode was a $0.62 \times 1.0 \mathrm{~cm}^{2}$ single-faced plate, provided by Dr. W. Haenni from CSEM, Neuchâtel, Switzerland. Prior to the experiments the electrode was polarized at $-3.0 \mathrm{~V}$ $v s . \mathrm{Ag} / \mathrm{AgCl}$ for $30 \mathrm{~s}$ to remove the hydrophobic film that covers the surface. After each measurement with 4-NP the electrode was thoroughly rinsed with water to remove any possible residues and ensure the reproducibility of the experiments. Electrochemical measurements were carried out using a model 273A EG\&G PARC potentiostat with the M270 software.

A $1.5 \times 10^{-3} \mathrm{~mol} \mathrm{~L}^{-1}$ stock solution of the pesticide (4nitrophenol, Aldrich 99\%) was prepared using water from the Milli-Q (Millipore) purification system. The buffer used was $0.1 \mathrm{~mol} \mathrm{~L}^{-1}$ Britton-Robinson (BR) $)^{23}$ with the $\mathrm{pH}$ adjusted to 6.0 by the addition of proper amounts of a 1.0 mol L ${ }^{-1} \mathrm{NaOH}$ solution. All reagents were analytical grade. Analytical curves were obtained by the standard addition method.

\section{Results and Discussion}

The square wave voltammogram recorded for a $1.5 \mathrm{x}$ $10^{-5} \mathrm{~mol} \mathrm{~L}^{-1} 4$-NP solution on the BDD electrode is shown in Figure 1. The total lack of a reverse current indicates that the electron transfer process is an irreversible one ${ }^{21}$ having a peak potential of $c a .1 .0 \mathrm{~V} v s . \mathrm{Ag} / \mathrm{AgCl}$.

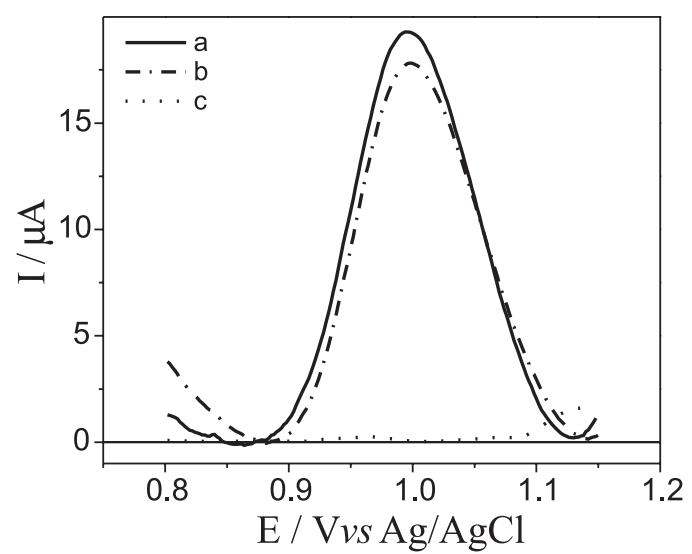

Figure 1. SWV response of the BDD electrode in $1.5 \times 10^{-5} \mathrm{~mol} \mathrm{~L}^{-1} 4-\mathrm{NP}$ (0.1 mol L-1 BR buffer, pH 6.0, $\left.a=50 \mathrm{mV}, \Delta E_{s}=2 \mathrm{mV}, f=100 \mathrm{~s}^{-1}\right)$. Curves corresponding to: total (a); direct (b) and reverse (c) currents.

Optimization of the analytical procedure involved a systematic study of the experimental parameters that affect the SWV response, namely, the $\mathrm{pH}$ of the medium, the frequency $(f)$, the pulse amplitude $(a)$ and the scan increment $\left(\Delta \mathrm{E}_{\mathrm{s}}\right)$. The results of these studies will be separately presented in the sequence.

\section{Influence of the $\mathrm{pH}$}

The effect of $\mathrm{pH}$ on $\mathrm{E}_{\mathrm{p}}$ and $\mathrm{I}_{\mathrm{p}}$ was examined for $1.5 \mathrm{x}$ $10^{-5} \mathrm{~mol} \mathrm{~L}^{-1} 4-\mathrm{NP}$ using the BDD electrode in a $0.1 \mathrm{~mol} \mathrm{~L}^{-1}$ 
BR buffer medium varying the $\mathrm{pH}$ in the interval 2.0-10.0. The peak potential was strongly $\mathrm{pH}$-dependent showing two linear regions that change slope at $c a$. $\mathrm{pH} 8.0$ (Figure 2) The two linear regions in the $\mathrm{E}_{\mathrm{p}}-\mathrm{pH}$ plot intercept at $\mathrm{pH}$ 7.4, a value very close to the $\mathrm{pK}_{\mathrm{a}}$ reported for 4-NP in the literature, that is, 7.2. ${ }^{25}$ On the other hand, the $\mathrm{I}_{\mathrm{p}} v s$. $\mathrm{pH}$ plot (Figure 2) revealed that the peak current has a maximum value for $\mathrm{pH} 6.0$ decreasing sharply in both directions. For this reason, all subsequent experiments using BDD electrodes were carried out at $\mathrm{pH}$ 6.0.

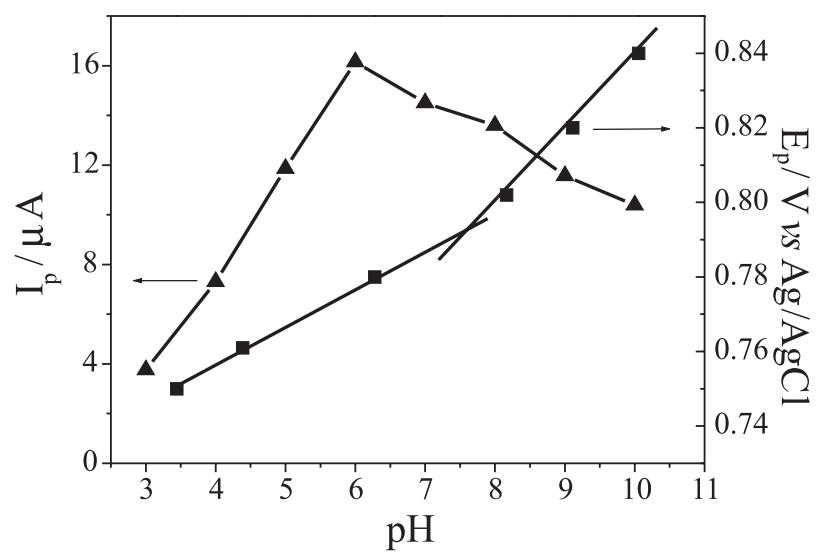

Figure 2. Influence of the $\mathrm{pH}$ on peak potential (ם) and peak current $(\boldsymbol{\Delta})$ for square wave voltammetry on boron-doped diamond electrode $\left([4-\mathrm{NP}]=1.5 \times 10^{-5} \mathrm{~mol} \mathrm{~L}^{-1}\right.$ in $0.1 \mathrm{~mol} \mathrm{~L}^{-1} \mathrm{BR}$ buffer, pH 6.0, with $\left.a=50 \mathrm{mV}, \Delta E_{\mathrm{s}}=2 \mathrm{mV}, f=100 \mathrm{~s}^{-1}\right)$.

Influence of the square wave frequency $(f)$

This parameter is of up-most importance in SWV since it determines the intensity of the signal and, in turn, the sensitivity of the technique. Figure 3 shows the set of voltammograms obtained for different frequency values up to $100 \mathrm{~s}^{-1}$. For larger values of $f$ the effect on the peak current is almost negligible.

The insert in Figure 3 indicates that the peak current is a linear function of frequency. According to the accepted theories for $\mathrm{SWV},{ }^{26}$ this behavior corresponds to a totally irreversible process controlled by adsorption of the species on the electrode surface. Moreover, for that type of system the peak potential should vary linearly with the logarithm of the frequency following the relationship: ${ }^{27}$

$\frac{\Delta E_{p}}{\Delta \log f}=\frac{2.3 R T}{\alpha n F}$

where $\alpha$ is the transfer coefficient and $n$ the number of electrons involved in the reaction, the other terms having their usual meaning. Figure 4 shows the dependence of $E_{p}$ with $\log f$ taken from the data of Figure 3 for 4-NP on the
BDD electrode. By means of equation (1) a value of 1.92 was determined for $\alpha n$. Preparative electrolyses of 4-NP indicate the transference of 2 electrons per 4-NP molecule thus suggesting a value of $\alpha$ somewhat larger than 0.5 , a common feature for organic molecules. ${ }^{26}$

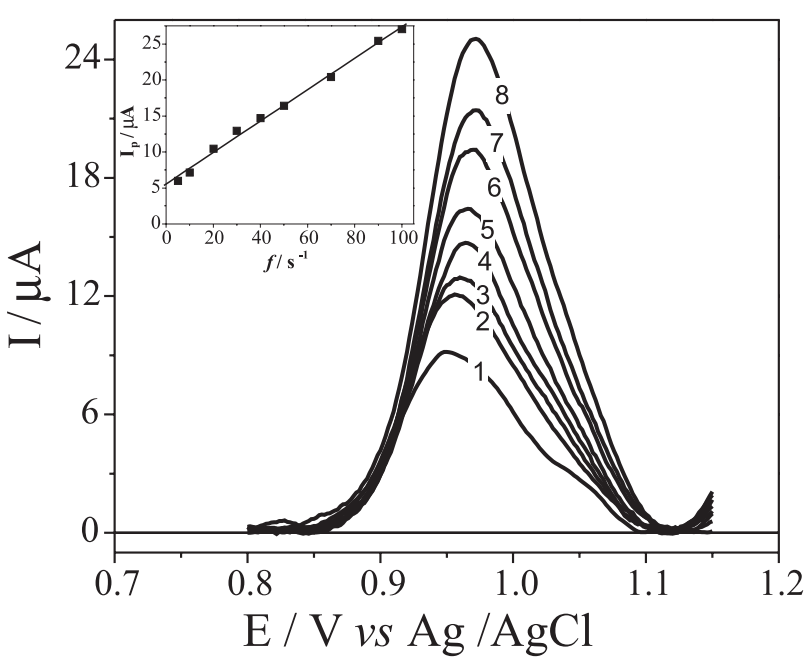

Figure 3. Effect of the frequency on the square wave voltammograms for $1.5 \times 10^{-5} \mathrm{~mol} \mathrm{~L}^{-1} 4-\mathrm{NP}$ in $0.1 \mathrm{~mol} \mathrm{~L}^{-1} \mathrm{BR}$ buffer, $\mathrm{pH}$ 6.0, with $a$ $=50 \mathrm{mV}$ and $\Delta E_{s}=2 \mathrm{mV}$. Frequencies: 5 (1), 20 (2), 30 (3), 40 (4), 50 (5), 70 (6), 90 (7) and 100 (8) $\mathrm{s}^{-1}$. Insert: linear dependence of the peak current with the square wave frequency.

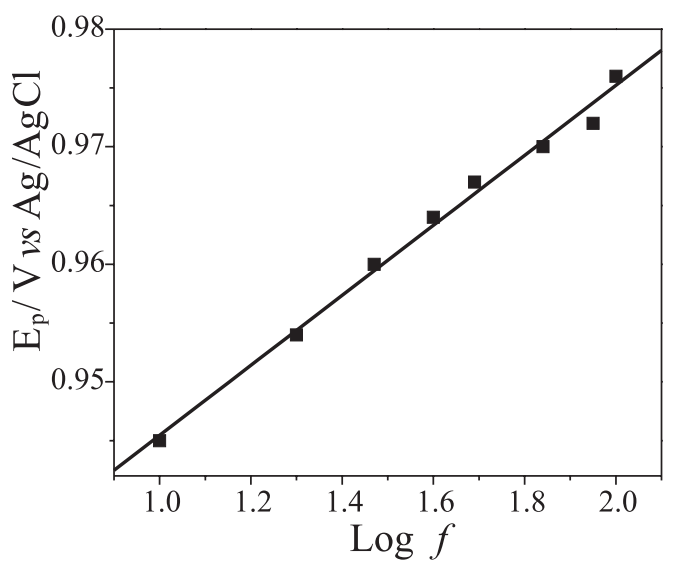

Figure 4. Linear dependence of the peak potential with the logarithm of square wave frequency for data extracted from Figure 3.

\section{Influence of the pulse amplitude (a)}

The pulse amplitude is another parameter that strongly influences the peak current in SWV thus determining the sensitivity of the technique. Figure 5 illustrates this effect with the results obtained for a $1.5 \times 10^{-5} \mathrm{~mol} \mathrm{~L}^{-1} 4-\mathrm{NP}$ solution on the BDD electrode. As expected from theory, ${ }^{27}$ the peak current has a practically linear variation with the pulse amplitude for values of $a$ lower than $50 \mathrm{mV}$ and 
reaches a plateau at around $70 \mathrm{mV}$. For the subsequent analytical applications, a value of $50 \mathrm{mV}$ was chosen for $a$.

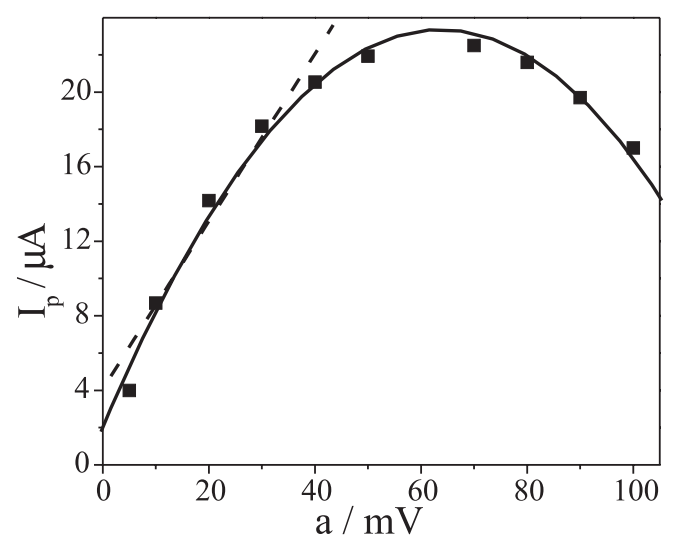

Figure 5. Dependence of the peak current with the square wave amplitude for experiments carried out under the following conditions: [4-NP] $=1.5 \times 10^{-5} \mathrm{~mol} \mathrm{~L}^{-1}$ in $0.1 \mathrm{~mol} \mathrm{~L}^{-1} \mathrm{BR}$ buffer, $\mathrm{pH} 6.0$, with $\Delta E_{s}=2 \mathrm{mV}$ and $f=100 \mathrm{~s}^{-1}$.

Additionally, the linear portion of the curve in Figure 5 allows an approximate calculation of the surface concentration $(\Gamma)$ of the adsorbed species through the following equation: ${ }^{26}$

$I_{p}=(5 \pm 1) 10^{2} q \alpha n^{2} F f a \Delta E_{s} \Gamma$

where $q$ is the electrode area, $a$ is the pulse amplitude and the other terms have already been defined. The calculation for $\Gamma$ yielded $9.5 \times 10^{-11} \mathrm{~mol} \mathrm{~cm}^{-2}$, a value that is more than three times higher than that previously measured for pentachlorophenol. ${ }^{22}$

\section{Analytical curve for 4-NP}

Figure 6 shows the square wave voltammograms obtained for the oxidation of 4-NP at different concentrations in $0.1 \mathrm{~mol} \mathrm{~L}^{-1} \mathrm{BR}$ buffer at $\mathrm{pH} 6.0$ as recorded after optimization of the experimental SWV parameters. The different curves were obtained using the standard addition method and the BDD electrode. The insert in Figure 6 corresponds to the analytical curve, that is, the linear dependence of $\mathrm{I}_{\mathrm{p}}$ with 4-NP concentration for the interval under investigation ( 3.0 to $50 \times 10^{-6} \mathrm{~mol} \mathrm{~L}^{-1}$ ).

For the determination of the detection limit (DL), the standard deviation of the mean value for ten voltammograms of the blank $\left(\mathrm{S}_{\mathrm{B}}\right)$, the slope of the straight line in the analytical curve and the equation below were used. ${ }^{28}$ The calculated value of DL for the BDD electrode was $1.7 \mathrm{x}$ $10^{-8} \mathrm{~mol} \mathrm{~L}^{-1}$ (or $2.8 \mu \mathrm{g} \mathrm{L}^{-1}$ ).

$L D=\frac{3 S_{B}}{b}$

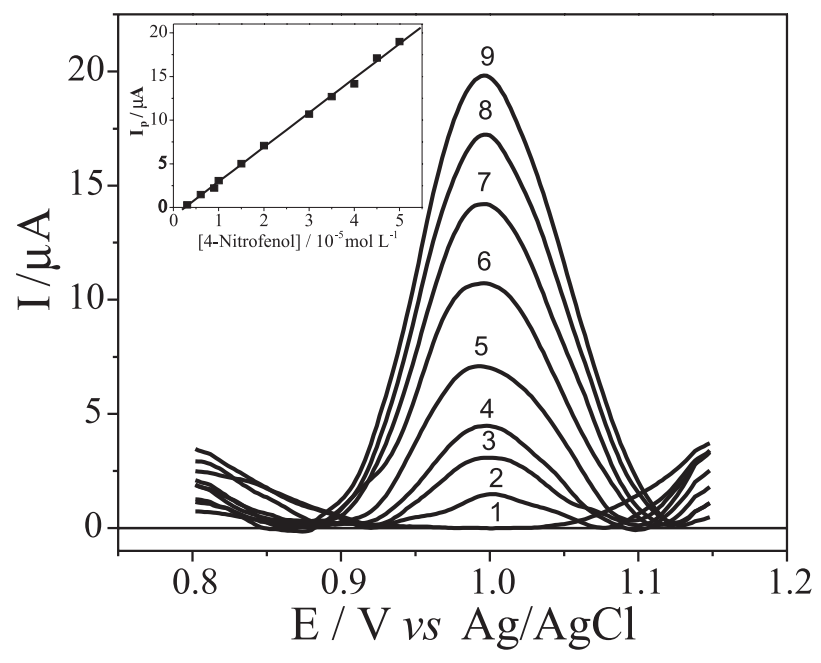

Figure 6. SWV response of the BDD electrode for different 4-NP concentrations: 0 (1) 0.6 (2); 1.0 (3); 1.5 (4); 2.0 (5); 3.0 (6); 4.0 (7), 4.5 (8) and 5.0 (9) x $10^{-5} \mathrm{~mol} \mathrm{~L}^{-1}$ in $0.1 \mathrm{~mol} \mathrm{~L}^{-1} \mathrm{BR}$ buffer, $\mathrm{pH}$ 6.0, with $a=50 \mathrm{mV}, \Delta E=2 \mathrm{mV}, f=100 \mathrm{~s}^{-1}$. Insert: linear dependence of the peak current with 4-NP concentration (Analytical curve for the oxidation process).

Once the 4-NP is capable of undergoing a reduction process at relatively low negative potentials, the same routines described above were followed to optimize that process for 4-NP on the BDD electrode. This will allow a comparison of the two sets of results for the same experimental system.

In this case and after optimization of the SWV conditions, a single and irreversible reduction peak was observed at ca. $-0.8 \mathrm{~V}$ vs. $\mathrm{Ag} / \mathrm{AgCl}$ for 4-NP in BR buffer at $\mathrm{pH}$ 6.0. The analytical curve in pure water solutions was also obtained by the standard addition method and the corresponding experimental results are presented in Figure 7 together with an insert showing the dependence of $I_{p}$ with 4-NP concentration.

The determination of the detection limit (DL) followed the same procedure described before. Here, the calculated value was $8.7 \times 10^{-8} \mathrm{~mol} \mathrm{~L}^{-1}$ (or $4.2 \mu \mathrm{g} \mathrm{L}^{-1}$ ) that practically coincides with those reported in the literature for $\mathrm{Hg}$ electrodes. ${ }^{89}$ Although that later value is slightly higher than the one obtained for the oxidation process on the BDD electrode it is still quite appropriate for several analytical determinations. The whole set of parameters measured for both the oxidation and the reduction processes are collected in Table 1.

\section{Conclusions}

The results reported here demonstrate that the combination of square wave voltammetry and the borondoped diamond electrode is a feasible alternative for the 


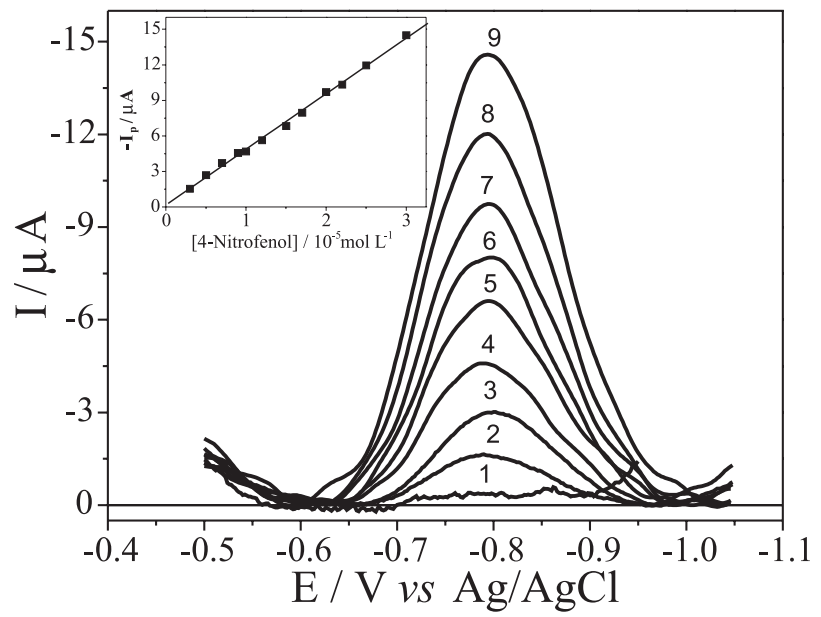

Figure 7. SWV response of the BDD electrode for different 4-NP concentrations: 0 (1), 0.3 (2); 0.7 (3); 1.0 (4); 1.5 (5); 2.0 (6); 2.2 (7); 2.5 (8) and 3.0 (9) $\times 10^{-5} \mathrm{~mol} \mathrm{~L}^{-1}$ in $0.1 \mathrm{~mol} \mathrm{~L}^{-1} \mathrm{BR}$ buffer, $\mathrm{pH}$ 6.0 , with $a=60 \mathrm{mV}, \Delta E_{s}=2 \mathrm{mV}, f=100 \mathrm{~s}^{-1}$. Insert: linear dependence of the peak current with 4-NP concentration (Analytical curve for the reduction process)

Table 1. Parameters from the analytical curves for 4-NP obtained by square wave voltammetry on boron-doped diamond electrodes

\begin{tabular}{|c|c|c|}
\hline \multirow[b]{2}{*}{ Parameters } & \multicolumn{2}{|c|}{ Values } \\
\hline & $\begin{array}{l}\text { Oxidation peak } \\
\qquad(1.0 \mathrm{~V})\end{array}$ & $\begin{array}{l}\text { Reduction peak } \\
(-0.8 \mathrm{~V})\end{array}$ \\
\hline Slope / (A L mol-1) & 0.3943 & 0.4696 \\
\hline Correlation coefficient & 0.9991 & 0.9985 \\
\hline Intercept / $(\mu \mathrm{A})$ & 0.9830 & 0.1635 \\
\hline${ }^{\mathrm{a}} \mathrm{S}_{\mathrm{B}} /(\mu \mathrm{A})$ & $7.9 \times 10^{-3}$ & $14.0 \times 10^{-3}$ \\
\hline Detection Limit / $\left(\mu \mathrm{g} \mathrm{L}^{-1}\right)$ & 8.4 & 12.1 \\
\hline
\end{tabular}

${ }^{\mathrm{a}} \mathrm{S}_{\mathrm{B}}$ is the standard deviation of the mean value for ten voltammograms of the blank.

analytical determination of 4-NP and related molecules in pure water. Moreover, the results obtained with both oxidation and reduction processes are practically equivalent showing even some advantages when dealing with oxidation.

The oxidation of 4-NP on a BDD electrode occurs in an irreversible manner with the species strongly adsorbed on the surface. Optimization of the experimental SWV parameters yielded a detection limit for 4-NP of $2.8 \mu \mathrm{g} \mathrm{L}^{-1}$ in pure water. In addition, the system can also be analyzed through a reduction process, keeping the other experimental conditions constant, with a detection limit still acceptable from an analytical viewpoint $\left(4.2 \mu \mathrm{g} \mathrm{L}^{-1}\right)$. In both cases, the DL in pure water is low enough to comply with the limits imposed by environmental and/or health authorities for human consumption $\left(30 \mu \mathrm{g} \mathrm{L}^{-1}\right)$. While for natural matrices it is well below the acceptable limit (100 $\left.\mu \mathrm{g} \mathrm{L}^{-1}\right)$.

\section{Acknowledgements}

The authors thank FAPESP (Procs. 01/08626-9 and 99/ 08050-8) and CNPq, Brazil, for the scholarships and financial support to this work.

\section{References}

1. U. S. Environmental Protection Agency, Fer. Regist. 1979, 44, 233.

2. Conselho Nacional do Meio Ambiente - (Environmental National Council in Brazil), details can be found at: www.agaambiental.com.br/leis/resoluo conama 20-86.doc, accessed in May 5, 2003.

3. Christophersen, M.J.; Cardwell, T.J.; Anal. Chim Acta 1996, 323,39 .

4. Castillo, M.; Domingues, R.; Alpendurada, M.F.; Barceló, D.; Anal. Chim Acta 1997, 353, 133.

5. Mussmann, P.; Levsen, K.; Radeck, W.; Fresenius J. Anal. Chem. 1994, 348, 654.

6. Turnes, M.I; Mejuto, M.C.; Cela, R.; J. Chromatogr. A 1996, 733, 395.

7. Vaz, C.M.P.; Crestana, S.; Machado, S.A.S.; Mazo, L.H.; Massaropi, M.R.C.; Avaca, L.A.; Electroanalysis 1997, 9, 956.

8. Hu, S.; Xu, C.; Wang, G.; Cui, D.; Talanta 2001, 54, 115.

9. Rodriguez, I.N.; Muñoz, J.A.; Cisneros, J.L.; Analyst 1997, 122, 601.

10. Carracedo, M.P.A.; Carra, R.A.G.; Misiego, A.S.; Electroanalysis 2002, 14, 433.

11. Michalkiewicz, S.; Tutaj, M.; Kaczor, M.; Malyszko, J.; Electroanalysis 2002, 14, 297.

12. Gandini, D.; Michauld, P.; Duo, I.; Maché, E.; Haenni, W.; Perret, A.; Comninellis, C.; New Diamond Front. Carbon Technol. 1999, 5, 9 .

13. Suffredini, H.B.; Machado, S.A.S.; Avaca, L.A.; J. Braz. Chem. Soc., in press.

14. Rao, T.N.; Fujishima, A.; Diamond Relat. Mater. 2001, 10, 1799.

15. Pleskov, Yu.V.; Russ. J. Electrochem. 2002, 38, 1411

16. Pannizza, M.; Michaud, P.A.; Iniesta, J.; Comninellis, C.; Annali Chim. 2002, 92, 995.

17. Marselli, B.; Garcia-Gomez, J.; Michaud, P.A.; Comninellis, C.; J. Electrochem. Soc. 2003, 150, D-79.

18. Canizares, P.; Martinhez, F.; Diaz, M.; Garcia-Gomez, J.; Rodrigo, M.A.; J. Electrochem. Soc. 2002, 149, D-118.

19. Rao, T.N.; Loo, B.H.; Sarada, B.V.; Terashima, C.; Fujishima, A.; Anal. Chem. 2002, 74, 1578.

20. Prado, C.; Murcott, G.C.; Marken, F.; Foord, J.S.; Compton, R.; Electroanalysis 2002, 14, 975.

21. Wang, J.; Chen, G.; Chatrathi, M.P.; Fujishima, A.; Tryk, D.A.; Shin, D.; Anal. Chem. 2003, 75, 935. 
22. Codognoto, L.; Machado, S.A.S.; Avaca, L.A.; Diamond Relat. Mater. 2002, 11, 1670.

23. Britton, T.S.; Robinson, R.A.; J. Chem. Soc. 1931, 458, 287.

24. Souza, D.; Machado, S.A.S.; Avaca, L.A.; Quim. Nova $\mathbf{2 0 0 3}$ 26,81 .

25. Wightman, P.G.; Fein J.B.; Appl. Geochem. 1999, 14, 319.

26. O‘Dea J.J.; Ribes, A.; Osteryoung, J.G.; J. Electroanal. Chem. 1993, 345, 287.
27. Lovric, M.; Komorsky-Lovric, S.; J. Electroanal. Chem. 1998 , 248, 239.

28. Skoog, D.A.; West, D.M.; Holler, F.L.; Fundamentals of Analytical Chemistry, Saunders College Publishing: Philadelphia, 1996, p. 320.

Received: December 2, 2002

Published on the web: July 2, 2003

FAPESP helped in meeting the publication costs of this article. 